\title{
Rapamycin-induced inhibition of HTLV-I LTR activity is rescued by c-Myb
}

\author{
Nicola J Rose*1 and Andrew ML Lever ${ }^{2}$
}

\author{
Address: ${ }^{1}$ Division of Retrovirology, National Institute for Biological Standards and Control, Blanche Lane, South Mimms, Potters Bar, \\ Hertfordshire EN6 3QG, UK and ${ }^{2}$ University of Cambridge Department of Medicine, Level 5, Addenbrooke's Hospital, Hills Road, Cambridge. \\ CB2 2QQ, UK \\ Email: Nicola J Rose* - nrose@nibsc.ac.uk; Andrew ML Lever - amll1@mole.bio.cam.ac.uk \\ * Corresponding author
}

Published: 3 April 2007

Retrovirology 2007, 4:24 doi:10.1186/1742-4690-4-24

This article is available from: http://www.retrovirology.com/content/4/I/24

(c) 2007 Rose and Lever; licensee BioMed Central Ltd.

This is an Open Access article distributed under the terms of the Creative Commons Attribution License (http://creativecommons.org/licenses/by/2.0), which permits unrestricted use, distribution, and reproduction in any medium, provided the original work is properly cited.
Received: 9 January 2007

Accepted: 3 April 2007

\begin{abstract}
Background: Rapamycin is an immunosuppressive which represses translation of transcripts harbouring a polypyrimidine motif downstream of the mRNA cap site through the mammalian target of rapamycin complex. It inhibits the abnormal autologous proliferation of $\mathrm{T}$-cell clones containing a transcriptionally active human T-lymphotropic virus, type I (HTLV-I) provirus, generated from infected subjects. We showed previously that this effect is independent of the polypyrimidine motifs in the viral long terminal repeat (LTR) $R$ region suggesting that HTLV-I transcription, and not translation, is being affected. Here we studied whether rapamycin is having an effect on a specific transcription factor pathway. Further, we investigated whether mRNAs encoding transcription factors involved in HTLV-I transcriptional activation, specifically CREB, Ets and c-Myb, are implicated in the rapamycin-sensitivity of the HTLV-I LTR.
\end{abstract}

Results: An in vitro analysis of the role of SRE- and NF- $\kappa B$-mediated transcription highlighted the latter as rapamycin sensitive. Over-expression of c-Myb reversed the rapamycin effect.

Conclusion: The sensitivity of HTLV-I transcription to rapamycin may be effected through an NF$\kappa \mathrm{B}$-pathway associated with the rapamycin-sensitive mTORCI cellular signalling network.

\section{Background}

The human T-lymphotropic virus, type I (HTLV-I) is the causative agent of a progressive neurological disorder, HTLV-I-associated myelopathy/tropical spastic paraparesis (HAM/TSP [1,2]) and adult T-cell leukaemia/lymphoma (ATLL $[3,4]$ ) in addition to a number of other autoimmune disorders.

HTLV-I-infected primary T-cell clones, derived from peripheral blood mononuclear cells (PBMC) from HAM/ TSP-affected individuals, can be classified according to their proliferation capability. Some clones display high proliferation levels in the absence of exogenous interleukin-2 (IL-2) whereas others do not [5]. This autologous proliferation, correlates with the presence of a transcriptionally active provirus [5] and is independent of IL-2 and the IL-2 receptor (IL-2R) [6]. It may contribute to the development of T-cell malignancy. The ability of the proliferating cells to induce bystander T-cell proliferation in an IL-2-dependent manner [6] may be an important component in the development of HAM/TSP and other HTLVI-associated autoimmune diseases. Conceivably, inhibiting this effect might be of value in treating these conditions. A notable feature of the HTLV-I-infected T-cell 
clones is the selective inhibition of the autonomous proliferation by the immunosuppressant rapamycin (sirolimus) but not by FK506 (tacrolimus) or cyclosporine A [5]. FK506, also an immunosuppressive drug, bears chemical structural similarity to rapamycin (reviewed in [7]).

The growth inhibitory properties of rapamycin are mediated through the mammalian target of rapamycin (mTOR) network. mTOR (or FRAP, RAFT, SEP, RAPT [8]) is a member of the phosphatidylinositol kinase-related kinases (PIKKs), a group of signalling molecules. These proteins seem to function at a checkpoint for nutritional status in $\mathrm{G}_{1}$ as well as in response to the phosphatidylinositol 3-kinase (PI3K)-dependent pathway. Of two mTOR complexes identified, mTORC1 responds to growth factors via the P13K pathway (reviewed in [9]). Following stimulation of this pathway by insulin or insulin-like growth factors, a conversion product enables phosphorylation of Akt. This pathway is linked to mTORC1 through a heterodimer of the tuberous sclerosis proteins TSC1 (hamartin) and TSC2 (tuberin), which negatively regulates mTORC1 signalling. TSC2 acts as a GTPase-activating protein for the Rheb GTPase which has been proposed to induce conformational change in, and activation of, mTORC1 thereby enabling phosphorylation of downstream factors. Akt has been observed to phosphorylate and inactivate TSC 2 and thus the inactivation of mTORC1 by the heterodimer is relieved. The mTORC1 multimeric complex regulates a number of pathways involved in cell mass including protein synthesis, transcription and ribosome biogenesis. One of these functions of mTORC1 is the constitutive phosphorylation of S6K1 and helicase factors, e.g. the translation inhibitor, 4E-BP1. This process was initially thought to be required for translation of the $5^{\prime}$ polypyrimidine tract (5' TOP) mRNA species (reviewed in [8]) but the mechanism by which mTORC1 controls this translation is now less certain in light of recent reports suggesting that it does not depend on S6K activity or S6 phosphorylation $[10,11]$. Cap-dependent translation control may be promoted through the association of mTORC1 with S6K1 through translation initiation factor, eIF3 [12].

The repressive effect of rapamycin is mediated through its formation of inhibitory complexes with cellular immunophilins, the FK506-binding proteins (FKBP). As with the cyclosporin A-cyclophilin complex, the FK506FKBP12 complex interacts with, and inhibits, calcineurin, which is required for transcriptional activation of IL-2 in response to T-cell antigen receptor binding. In contrast, the rapamycin-FKBP12 gain-of-function complex interacts with mTORC1 inhibiting downstream signalling from mTORC1 by an as yet uncertain mechanism (reviewed in [9]). Rapamycin was reported to regulate cap-dependent translation of an increasing number of cellular genes through a mechanism dependent upon the mRNA possessing a $5^{\prime}$ TOP downstream of the cap site [13-15].

We have previously investigated the nature of the rapamycin sensitivity of the T-cell clones. We have shown that polypyrimidine motifs present downstream of the HTLVI cap site do not contribute to the rapamycin-sensitivity of the virus [16] raising the possibility that the observed reduced proliferation of HTLV-I-infected T-cell clones is a result of sub-optimal viral transcription rather than dysregulated translation. Through the mTORC1 network, rapamycin may down-regulate a pathway linked to translation of a gene which gives rise to a transcription factor with HTLV-I LTR binding capability. Alternatively rapamycin may be inhibiting HTLV-I and T cell proliferation through independent mechanisms.

HTLV-I transcriptional control is mediated primarily by the viral trans-activating protein, Tax, which interacts indirectly with the viral $5^{\prime}$ long terminal repeat (LTR). This interaction occurs through complex formation with cellular transcription factors for which there are binding motifs in the $\mathrm{U} 3$ region. Of the transcription factors involved, the binding of the cAMP-responsive element-binding protein (CREB) to core regions of the three 21-bp imperfect repeats in the U3 region (reviewed in [17]) is central to efficient viral transcription. Other transcription factors reported to play a role in viral promoter activity are the Ets1 and Ets2 proteins [18] and c-Myb proteins. For the latter there are reported to be both high- and low-affinity binding sites $[19,20]$. Ets1 is preferentially expressed in lymphocytes and is linked to oncogenesis in humans (reviewed in [21]). The c-myb gene is predominantly expressed in haematopoietic cells, is involved in the control of normal cell proliferation, and has been implicated in the induction of neoplasia (reviewed in $[22,23]$ ). cMyb has been suggested to initiate viral transcription following integration into the host genome independently of Tax. Production of the viral Tax protein is thereby enabled and Tax successfully competes with c-Myb for further recruitment of CBP [24]. Tax down-regulates the c-myb promoter $[25,26]$ and may prevent production of further $\mathrm{c}-\mathrm{Myb}$. The trans-activation through formation of a TaxCREB-CBP complex at the enhancer elements of the HTLV-I LTR is essential for highly efficient viral transcription [27]. The Tax-independent binding of Ets 1 transcription factor binding may also be important in early transcription either from de novo infection or from a latent provirus [18].

In addition to its direct function in the virus lifecycle, the mechanistic role of Tax in cellular dysfunction likely relates to its transactivation of the promoters of several 
cellular genes. As reviewed by Jeang [28], Tax has been shown to dysregulate cellular gene transcription by exploiting four signalling pathways: CREB/ATF, NF- $\mathrm{KB}$, SRF, and AP-1.

Our previous studies excluded a direct effect of rapamycin on HTLV-I mRNA [16] thus in this study we sought to elucidate the rapamycin-sensitive factor and pathway upstream of HTLV-I transcription which likely impacts on LTR activity. We hypothesise that a protein involved in transcriptional control of the virus may itself be regulated by rapamycin, and potentially forms part of the mTORC1 signalling network. The major protein candidates were CREB, Ets1 and 2, and c-Myb, through their known interaction with the HTLV-I LTR. Since these protein candidates function through the SRE and NF- $\mathrm{kB}$ pathways we investigated the effect of rapamycin on SRE and NF- $\mathrm{KB}$ reporter constructs in transfection experiments: we subsequently identified the NF- $\kappa \mathrm{B}$ pathway as responsive to rapamycin. Over-expression of c-Myb was able to counteract the rapamycin-induced repression of the wild type HTLV-I 5' LTR, thereby corroborating the importance of an NF-kB pathway.

\section{Results and Discussion \\ Rapamycin affects an NF- KB-dependent pathway}

We sought to identify the HTLV-I-associated transcription factor pathway responsible for the rapamycin-sensitivity. We have previously shown that a COS- 1 cell-based in vitro system, as well as pilot studies in Jurkat T-cells, sufficiently mimicked the scenario witnessed in T-cell clones [16], supporting the use of this in vitro system to further characterise elements of the mechanism of HTLV-I rapamycinsensitivity. Here, we established that an NF-kB-responsive promoter construct was sensitive to rapamycin when cotransfected into COS-1 with the Tax expressor, whereas the SRE-responsive promoter construct was not (data not shown). Since c-myb is predominantly expressed in hematopoietic cells, the use of COS-1 cells minimises the levels of endogenous c-Myb present. In transfected COS-1 cells the activity of the NF-kB-responsive promoter construct $(2 \times 18$-CAT $)$ in the presence of Tax was reduced in the presence of 20-120 nM rapamycin to approximately $65 \%$ of the zero rapamycin control $(P<0.002$ Student's paired $t$ test). In contrast, the activity of the SRE-responsive promoter construct (c-fos-SRE-CAT) in the presence of Tax and $120 \mathrm{nM}$ rapamycin was virtually unchanged at $95 \%$ of the zero rapamycin control $(P>0.5$ Student's paired $t$ test; Figure 1). These data suggest that an NF-KBresponsive pathway is involved in the rapamycin sensitivity of HTLV-I. Cell number, growth and transfection efficiency were not affected by the presence of rapamycin as assessed by transient transfection of COS-1 cells with a GFP expression plasmid (data not shown).

\section{Over-expression of the c-myb gene, but not the CREB or} Ets I genes rescues down-regulated promoter activity

We have shown that an NF-KB but not an SRE-responsive pathway is rapamycin sensitive. Since c-myb expression is regulated in part through members of the NF- $\mathrm{KB}$ transcription factor family [29] this finding suggested a potential link between c-Myb and HTLV-I provirus sensitivity to rapamycin. We corroborated our data from the previous experiment by determining the effect of over-expression of an NF-אB-specific protein on HTLV-I LTR activity in the presence of rapamycin. The HTLV-I Tax protein transactivates the c-fos promoter through the serum response element (SRE) [30] and the c-myb promoter through an NF$\kappa \mathrm{B}$ pathway [26]. Tax protein is known to antagonise the transcriptional activity of c-myb [26]. Neither the tax nor the $c-m y b$ genes in the protein expression constructs employed in our study are controlled by their native promoters, rather the backbone plasmid, pcDNA3, has the CMV immediate early promoter (previously determined as rapamycin-insensitive [16] and Figure 2A) to drive high expression. This is further illustrated in Figure $2 \mathrm{~B}$ in which the level of c-Myb protein does not differ significantly in the presence of $60 \mathrm{nM}$ rapamycin when compared to the rapamycin-negative control. This alleviates the problem of the expressed Tax and c-Myb proteins reciprocally interfering with transcriptional activity.

Co-transfection of neither the Ets1 expression vector, $\Delta$ EBEts1, nor the backbone vector, $\triangle \mathrm{EB} \Phi$, was able to restore the rapamycin-induced down-regulation of CRCAT (Figure 3A; $P>0.1$, Student's paired $t$ test). Co-transfection of the backbone vector, pcDNA3, also did not alter the rapamycin sensitivity of CR-CAT in the presence of Tax [16] (Figure 3B) nor did the addition of the CREB expression construct, pcDNA3CREB, have any effect on this sensitivity. There is a trend to reduction in HTLV-I LTR activity in the presence of the CREB expression construct with notably, transfection of a $2 \times$ amount also failing to rescue the activity of the CR-CAT promoter. In marked contrast co-transfection of the c-Myb expression construct, pcDNA3-c-myb reversed the rapamycin effect with evidence of a heightened effect at the $2 \times$ amount (Figure $3 \mathrm{~B})$. At the highest rapamycin concentration there is a significant difference between the effect of c-Myb and that of either CREB or pCDNA3 $(P<0.01$, Student's paired $t$ test).

\section{U3 deletion mutants and the wild type are comparably sensitive to rapamycin and FK506}

To determine whether c-Myb is a protein within the NF$\kappa \mathrm{B}$ transcription pathway that contributes to the decrease in HTLV-I transcriptional activity in the presence of rapamycin we generated HTLV-I LTR-CAT constructs from which sequences corresponding to published c-Mybbinding motifs in the $\mathrm{U} 3$ region were deleted. Similar constructs were generated in which CREB- and Ets-binding 


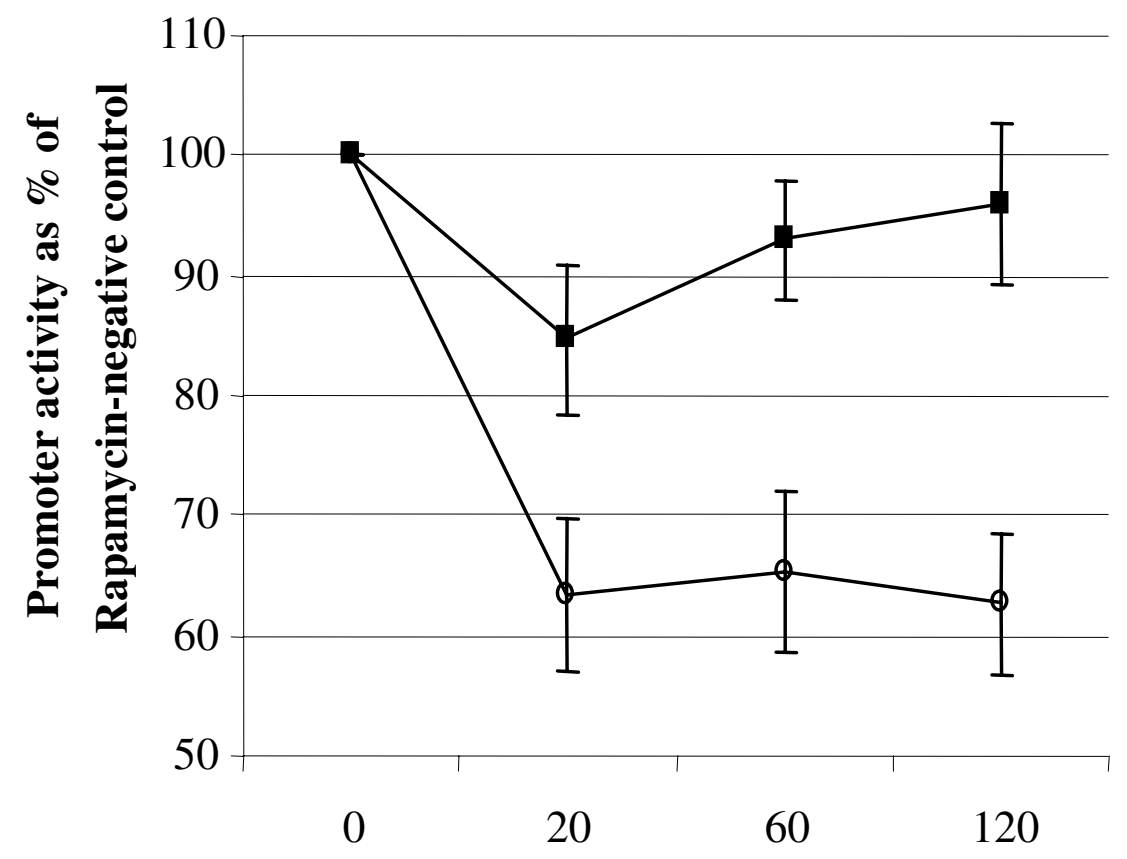

\section{Rapamycin concentration/nM}

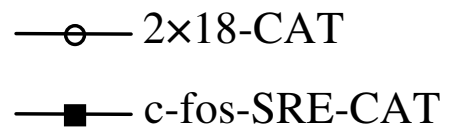

\section{Figure I}

The effect of rapamycin on an SRE-responsive (c-fos-SRE-CAT) and an NF- $\kappa$ B-responsive construct $(2 \times 18-C A T)$, each cotransfected with the pcDNA3Tax/Rex construct, is shown. CAT acetylation values are given as the percentage of the rapamycin-negative control. Mean values of three independent triplicate assays are illustrated \pm SEM.

motifs were deleted (Figure 4A). No change in HTLV-I LTR activity in the presence of rapamycin would suggest that the binding motif of a rapamycin-sensitive protein has been deleted.

The activities of the wild type promoter and each of the U3 mutant promoters in the absence and presence of rapamycin, when co-transfected into COS-1 cells with the Tax expressor, are illustrated in Figure 4B. Results from at least three independent experiments $( \pm$ SEM) are illustrated for the control construct, pIEP1-CAT, and the wild type and deletion constructs. As with the wild type promoter, the activity of each of the deletion mutants in the presence of three concentrations of rapamycin, $20 \mathrm{nM}, 60$ $\mathrm{nM}$, and $120 \mathrm{nM}$, was less than that of the rapamycin-negative controls. The differences between the activities of each of the experimental constructs and the control at the highest concentration of rapamycin are not significant $(P$
$>0.5$, paired Student's paired $t$ test) whereas the values for pIEP1-CAT and CR-CAT were significantly different $(P<$ 0.05 , paired Student's paired $t$ test). CR-CAT is clearly more susceptible to rapamycin inhibition than pIEP1CAT despite the latter having some NF- $\kappa \mathrm{B}$ response elements. This may be a dose effect as the pIEP1-CAT activity begins to fall slightly at the higher concentrations of rapamycin.

In microarray and proteomics studies of genes regulated by rapamycin in $\mathrm{T}$ cells [31] the c-myb gene was highlighted as being translationally unaffected by rapamycin as was ELK1, a member of the Ets oncogene family, and $A T F 2 / C R E B P 1$. We have highlighted the reduction in available c-Myb as being a potential downstream effect of translational control by rapamycin, thus factors upstream in the c-Myb activation pathway are likely candidates for the site of rapamycin sensitivity. Oh and Reddy review 
A

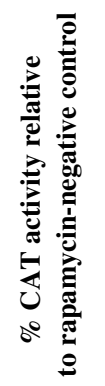

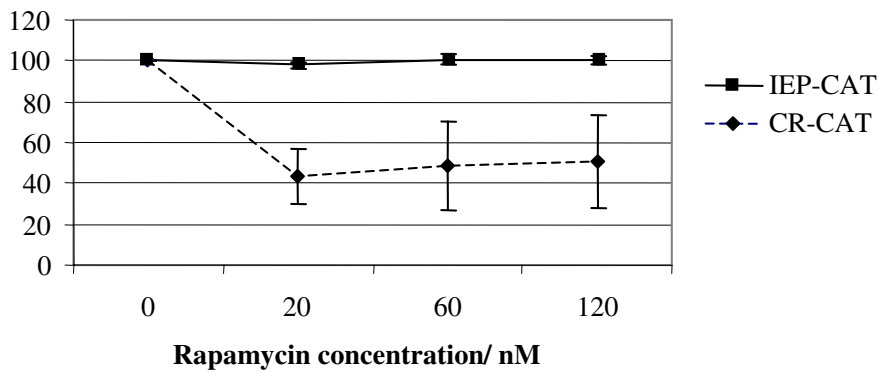

B

Rapamycin/nM $\quad 0 \quad 20 \quad 60$

\section{Figure 2}

The activities of the wild type HTLV-I LTR (CR-CAT) and the CMV promoter construct (PIEPI-CAT) in the presence and absence of rapamycin are illustrated. CAT acetylation values are given as the percentage of the rapamycin-negative control for each construct. Mean values of three independent assays are illustrated \pm SEM (A). Levels of c-Myb protein from cells grown in the presence and absence of rapamycin, as detected in a western blot, are shown. A representative blot of a duplicate experiment is shown (B).

some of these cofactors which include CBP and Ets-2 [23]. Interestingly, Grolleau et al. showed that intracellular levels of the Ets2 repressor factor (ERF) mRNA were found to increase three-fold in rapamycin-treated cells (13). Thus ERF might sequester the Ets-2 factor available for acting as a cofactor to c-Myb. Phan and colleagues [32] identified a rapamycin-sensitive regulator of c-myb expression. CMAT ( $\underline{\mathrm{c}}-\underline{m} \gamma b$ in $\underline{\text { activated }} \mathrm{T}$ cells) binds to a region of the c-myb promoter thereby enhancing expression. Concentrations of rapamycin in excess of $1 \mathrm{ng} / \mathrm{ml}$ prevented the CMAT complex formation at the promoter seen in the 'no rapamycin' control. In contrast with the scenario seen in
A

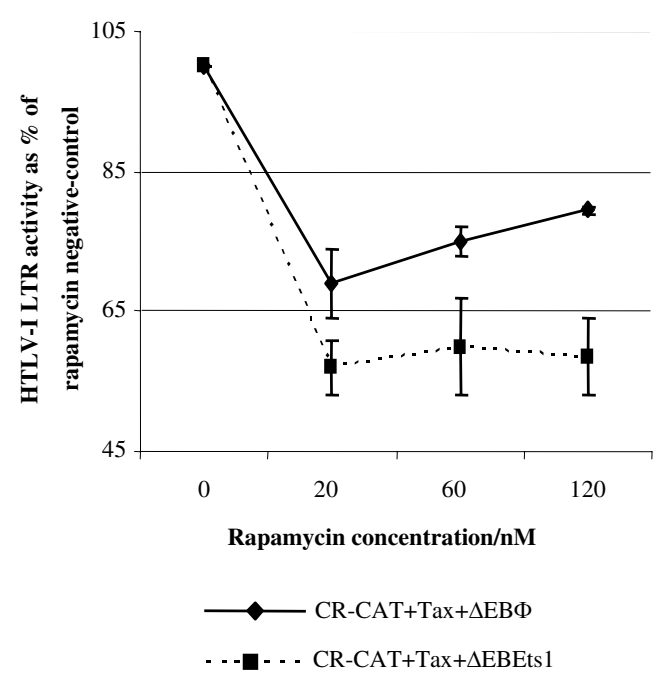

B

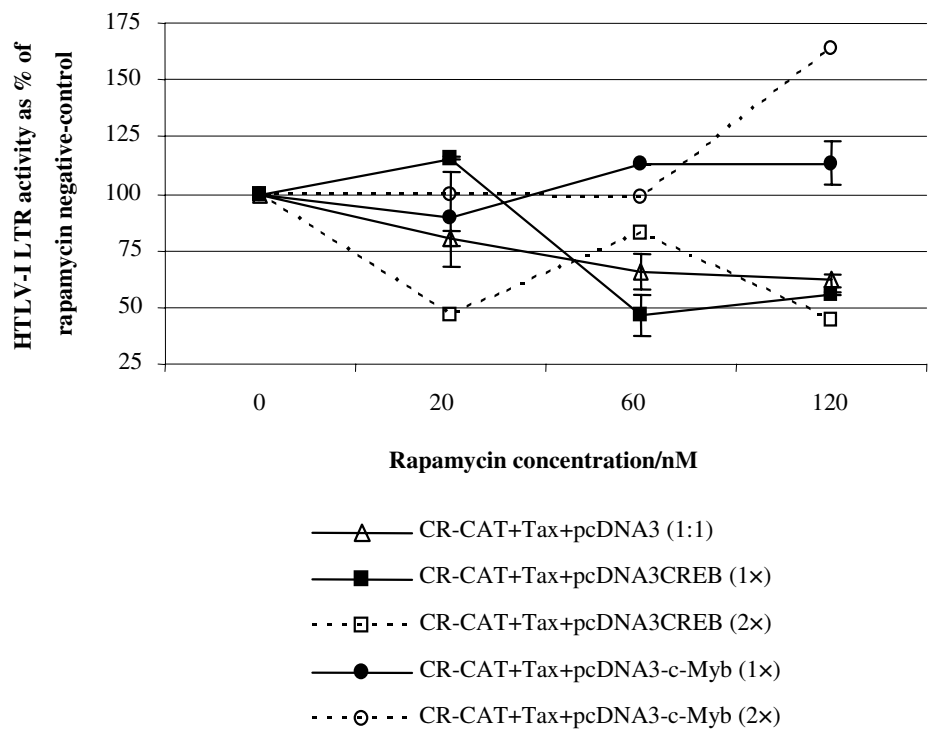

Figure 3

The effect of over-expression of c-Ets I (A) and c-Myb and CREB (B) on the promoter activity of CR-CAT in the presence and absence of rapamycin is illustrated. CAT acetylation values are given as the percentage of the rapamycin-negative control for each construct. Mean values of duplicate independent assays are illustrated \pm SEM. 
A

\begin{tabular}{|c|c|c|c|c|c|c|}
\hline & & & Absolute & $\begin{array}{l}\mathrm{d} \% \mathrm{CA} \\
\text { compa }\end{array}$ & $\begin{array}{l}\text { ylation of } \\
\text { CR-CAT }\end{array}$ & mutants \\
\hline & & & & & & \\
\hline & & & Absolute & Fold & Absolute & Fold \\
\hline CR-CAT & 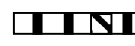 & $1: \square$ & 6.9 & 1 & 12.3 & 1 \\
\hline $\mathrm{CR}(\Delta \mathrm{EI})-\mathrm{CAT}$ & {$[\mathbf{M U}$} & 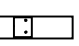 & 3.1 & 0.4 & 6.6 & 0.5 \\
\hline $\mathrm{CR}(\Delta \mathrm{EII})-\mathrm{CAT}$ & $\square \mathbf{\nabla}$ & L.] & 2.1 & 0.3 & 10.8 & 0.9 \\
\hline $\mathrm{CR}(\Delta \mathrm{EIII})-\mathrm{CAT}$ & $\square \square \square$ & & 2.6 & 0.4 & 10.9 & 0.9 \\
\hline $\mathrm{CR}(\Delta \mathrm{Ets})-\mathrm{CAT}$ & प्र I & $1.1 \square$ & 2.5 & 0.4 & 9.5 & 0.8 \\
\hline $\mathrm{CR}(\Delta \mathrm{Myb})-\mathrm{CAT}$ & $\square \mathbf{V I}$ & $\sqsupset$ & 3.1 & 0.4 & 16.0 & 1.3 \\
\hline
\end{tabular}

B

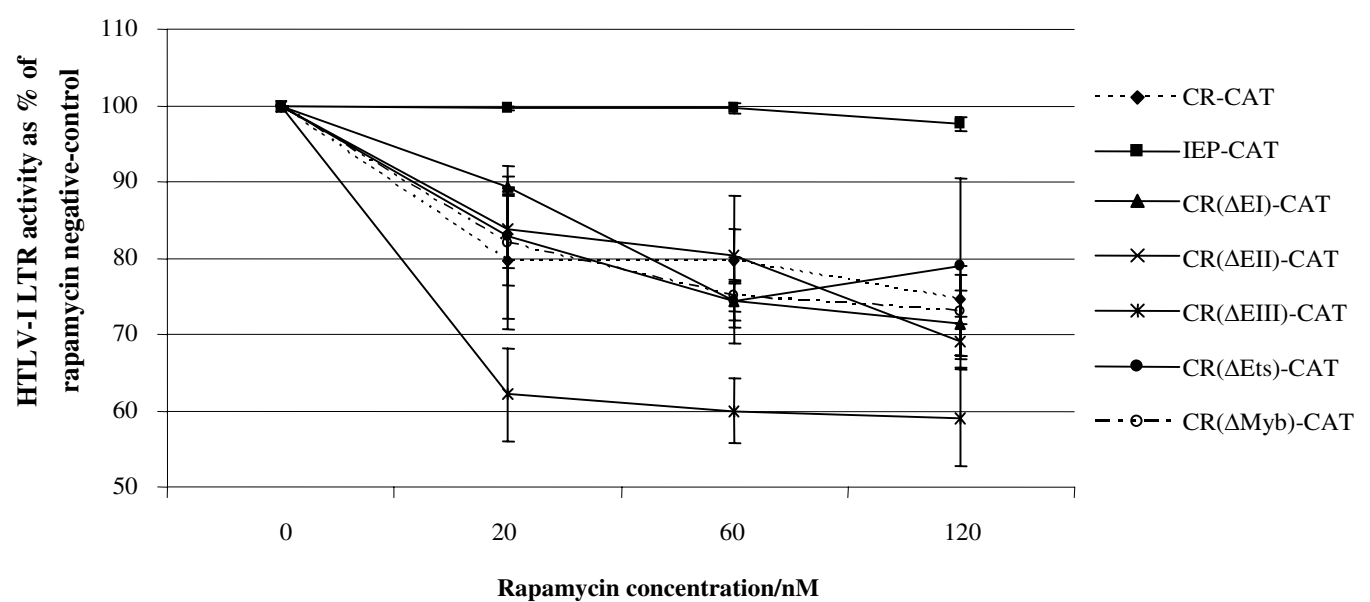

\section{Figure 4}

A. The region deleted in each HTLV-I LTR mutant, with respect to the wild type (CR-CAT) is illustrated schematically. Basal and Tax-trans-activated promoter activity for each mutant is shown compared to the wild type. Absolute CAT acetylation values are given. B. The activities of the wild type HTLV-I LTR and the deletion mutant HTLV-I LTRs in the presence and absence of rapamycin are illustrated. CAT acetylation values are given as the percentage of the rapamycin-negative control for each construct. Mean values of three independent assays are illustrated \pm SEM. 
the HTLV-I-infected T-cell clones, however, the authors demonstrated that cyclosporin A had the same effect as did rapamycin on c-myb promoter activity.

More recently, rapamycin has been reported to repress replication of HIV-1 [33]. In the same manner as we have previously reported for HTLV-I, the repression was reversed by FK506 [16]. The authors proposed that the point of action of rapamycin in the HIV-1 lifecycle is transcription.

\section{Conclusion}

In conclusion we have identified an NF- $\mathrm{KB}$-associated pathway of HTLV-I activation as being sensitive to the presence of rapamycin: repression of this pathway can be alleviated by expression of c-Myb protein. Tax is reported to repress c-Myb gene expression thereby enabling efficient Tax-driven viral expression, thus our observations highlight that the mechanism for the rapamycin-sensitivity of HTLV-I-infected T-cell clones is likely to be an upstream component of the NF- $\mathrm{KB}$ pathway. A reduction of c-Myb cellular levels is known to block T cells in late G1 of the cell cycle [34] however, from the deletion mutant studies it is difficult to construct a direct link between Myb over-expression counteracting the rapamycin inhibition of transcription and the lack of effect of the Myb response element deletion since Tax and Myb to some extent compete in activating HTLV-I. It seems most likely that rapamycin is inhibiting HTLV transcription through an mTORC1-related NF-kB pathway, and in the T cell clones inhibiting the abnormal proliferation of the cells through a second, possibly also mTORC1-related, NF- $\kappa B$ regulated pathway. In the absence of rapamycin it is highly likely that the latter is responsive to the viral Tax protein.

Of note, it has been reported that induction of $c-m y b$ expression can be inhibited through blocking of the PI3K pathway [35]. In combination with our data this observation would suggest that the translational control of the c$m y b$ mRNA is linked to the PI3K-mTORC1 pathway and thus repressible by rapamycin. The specificity of this pathway, which is clearly distinct from Cyclosporin-A mediated effects on $\mathrm{T}$ cell proliferation, highlights the involvement of the specific intracellular immunophilin pathway and merits serious further investigation as it would appear to be a novel route for virus induced cell proliferation which may be a target for prevention of virus induced neoplasia.

\section{Methods PCDNA3-CREB construction}

The rat CREB expression cassette in plasmid T7 $\beta$ CR1 was removed using HindIII and EcoRI and cloned into identical sites of pcDNA3 (Invitrogen). Correct cloning was identified by sequencing.

\section{Construction of U3 deletion mutants}

Plasmid CR-CAT comprises the U3, R and the 5 ' region of U5 of HTLV-I, and has been described previously [36]. The sequence of the $\mathrm{U} 3$ through the U3-R boundary region is illustrated (Figure 1). CR-CAT was subjected to PCR mutagenesis using Pfu DNA polymerase (Stratagene). Sequence flanking the region to be deleted was amplified using opposing oligonucleotides. A $10 \mathrm{ng}$ amount of plasmid was amplified in a $50 \mu \mathrm{l}$ reaction volume comprising $1 \times$ native reaction buffer (Stratagene), 3.5-5 $\mu \mathrm{M} \mathrm{MgCl}_{2}$ (depending on primer pair), $0.25 \mathrm{mM}$ each dNTP, $0.12 \mu \mathrm{M}$ each oligonucleotide and 0.02 units $P f u$ DNA polymerase. A single incubation of $96^{\circ} \mathrm{C}$ for 45 $\mathrm{s}$ was followed by 30 cycles comprising $96^{\circ} \mathrm{C}$ for $45 \mathrm{~s}$, $37^{\circ} \mathrm{C}$ for $45 \mathrm{~s}$ and $72^{\circ} \mathrm{C}$ for $10 \mathrm{~min}$ and an additional single extension step at $72^{\circ} \mathrm{C}$ for 10 min Oligonucleotides used to generate $\mathrm{CR}(\Delta \mathrm{EI})$-CAT were IR ( $5^{\prime}$ tta gag gcc $t \mathrm{CA}$ GAC TTC TGT TTC TCG G3') and IF (5'gta gcg ata tcA GCA CCG GCT CGG G3'); CR( $\triangle$ EII)-CAT were IIR (5'tta gag gcc $t$ CC GGG GGG AGA CGT CAG AGC C3') and IIF (5'tag cga tat $c$ AT AAG CTC AGA CCT CC3'); CR( $\triangle$ EIII)-CAT were IIIR ( 5 'gca tag gcc $t$ TT GAC AAA CAT GG 3 ') and IIIF (5'gta gcg ata tcG GCA CGC ATA TGG C3'); CR( $\Delta$ Ets)-CAT were EtsR ( 5 'tta gag gcc $t$ TA TGA TTT GTC TTC AG3') and EtsF (5'gta gcg ata tcC GTC CTC AGG CGT TG3'); $\mathrm{CR}(\Delta \mathrm{Myb})$-CAT were MybR ( 5 'tta gag gcc tTT TAT AGA CTC CTG3') and MybF (5'gta gcg ata tcG GGG CTC GCA TCT CTC C3'); where sequences in upper case are complementary to HTLV-I LTR sequence, those in italicised lowercase introduce a $S t u I$ (IR, IIR, IIIR, EtsR, MybR) or an EcoRV (IF, IIF, IIIF, EtsF, MybF) restriction site, and those in plain lowercase represent random sequence. Gel purified amplicon was restricted with StuI and EcoRV and circularised using a Rapid Ligase kit (Boehringer Mannhein). The primers designed to remove the high-affinity c-Myb binding motif were designed to retain the TATA box and the U3-R boundary. Correct deletions were confirmed by sequencing.

\section{Transient transfections}

To assess the activity of the NF- $\mathrm{KB}$ and SRE-responsive reporter constructs: $5 \mu \mathrm{g}$ of each plasmid $(2 \times 18$-CAT or c-fos-SRE-CAT, respectively) were transiently transfected with an equal amount of pcDNA3Tax/Rex into $5-\mathrm{cm}$ diameter tissue culture dishes seeded with $0.6 \times 10^{6} \mathrm{COS}$ 1 cells 16 h previously, using the DEAE-dextran method [37]. Briefly, cells were washed with $1 \times$ phosphate buffered saline (PBS) and plasmid and $50 \mu$ DEAE-dextran $(10 \mathrm{mg} / \mathrm{ml}$ in $1 \mathrm{M}$ Tris- $\mathrm{HCl} ; \mathrm{pH} 7.4)$ was added in $1 \mathrm{ml}$ PBS. Following a $30 \mathrm{~min}$ incubation at $37^{\circ} \mathrm{C}$ with $5 \%$ $\mathrm{CO}_{2}, 3.5 \mathrm{ml}$ DMEM (Invitrogen) supplemented with 80 $\mu \mathrm{M}$ chloroquine was added. Following incubation for a further $2.5 \mathrm{~h}$ cells were incubated with $10 \%(\mathrm{w} / \mathrm{v}) \mathrm{DMSO}$ in DMEM for 2 min, washed with DMEM and resuspended in DMEM media supplemented with $10 \%$ fetal 
bovine serum and $1 \%$ penicillin-streptomycin, and incubated for $24 \mathrm{~h}$ at $37^{\circ} \mathrm{C}$ with $5 \% \mathrm{CO}_{2}$.

To assess the effect of over-expressed protein on wild type HTLV-I LTR activity in the presence of rapamycin: cotransfection of $250 \mathrm{ng}$ transcription factor expression plasmids was performed with an equal amount of CR-CAT and pcDNA3Tax/Rex in COS-1 cells as above.

To assess the HTLV-I LTR deletion mutants: $1 \mu \mathrm{g}$ each CRCAT deletion mutant was either transiently transfected alone or co-transfected, with $1 \mu \mathrm{g}$ pcDNA3Tax/Rex (HTLV-I Tax expression vector), as above.

When required, rapamycin (Sigma) was added to the post-transfection culture medium at a final concentration of 0, 20, 60 or $120 \mathrm{nM}$. FK506 (Calbiochem) was added to a final concentration of $2 \mu \mathrm{M}$ either alone or in combination with rapamycin.

For all transfection experiments, the levels of CAT acetylation products in $30 \mu \mathrm{l}$ cell supernatant were assessed $24 \mathrm{~h}$ post-transfection by thin-layer chromatography, quantified on an Instant Imager (Canberra Packard) and expressed either as absolute acetylation values or as a percentage of the levels of CAT acetylation of the rapamycinnegative control.

\section{Western blot analysis}

To assess the levels of expressed protein in the presence of rapamycin (0-60 $\mathrm{nM}$ range), transfections were carried out as above with each expression plasmid. Total cellular protein from $1 \times 10^{6}$ COS- 1 cells transfected with pcDNA3-c-myb was harvested and 1/20 vol. blotted onto a nitrocellulose membrane using standard techniques. The primary antibody was a rabbit anti-c-Myb polyclonal antibody at a 1:500 dilution; the secondary goat antimonkey horseradish peroxidase-linked antibody was applied at a 1:1000 dilution. Proteins were detected using ECL reagents (Amersham), according to the manufacturer's instructions, followed by autoradiography.

\section{Competing interests}

The author(s) declare that they have no competing interests.

\section{Authors' contributions}

NR participated in the design of the study, performed the experiments and drafted the manuscript. AMLL conceived of the study, participated in its design and helped draft the manuscript. Both authors analysed the data and read and approved the final manuscript.

\section{Acknowledgements}

Many reagents were generous gifts. Plasmids CR-CAT and pcDNA3Tax/ Rex were provided by Dr Marie-Christine Dokhélar; the constructs $\triangle E B \Phi$ and $\triangle E B-E t s I$ were provided by Prof Jacques Ghysdael; the rabbit anti-cMyb antibody and the c-Myb expression plasmid were provided by $\mathrm{Dr}$ Roger Watson; plasmid T7 $\beta C R I \alpha$ was provided by Dr Helen Hurst; plasmid c-fos-SRE-CAT was provided by Prof Chou-Zen Giam; plasmid 2 × 18 CAT was provided by Dr Jane Allen. This work was supported in part by a grant from The Wellcome Trust and the UK Department of Health.

\section{References}

I. Gessain A, Barin F, Vernant JC, Gout O, Maurs L, Calender A, de Thé $\mathrm{G}$ : Antibodies to human T-lymphotropic virus type-I in patients with tropical spastic paraparesis. The Lancet 1985 , ii:407-409.

2. Osame M, Usuku K, Izumo S, Ijichi N, Amitani H, Igata A, Matsumoto $M$, Tara M: HTLV-I-associated myelopathy, a new clinical entity. The Lancet 1986, i: I03 I-1032.

3. Poiesz B, Ruscetti FW, Gazdar AF, Bunn PA, Minna JD, Gallo RC: Detection and isolation of type $C$ retrovirus particles from fresh and cultured lymphocytes of a patient with cutaneous T-cell lymphoma. Proceedings of the National Academy of Sciences USA 1980, 77:74I5-74I9.

4. Yoshida M, Miyoshi I, Hinuma $Y$ : Isolation and characterization of retrovirus from cell lines of human adult $T$-cell leukemia and its implication in the disease. Proceedings of the National Academy of Sciences USA 1982, 79:203I-2035.

5. Höllsberg P, Wucherpfennig KW, Ausubel LJ, Calvo V, Bierer BE, Hafler DA: Characterization of HTLV-I in vivo infected T cell clones. Journal of Immunology 1992, I 48:3256-3263.

6. Wucherpfennig KW, Höllsberg P, Richardson JH, Benjamin D, Hafler DA: $\mathbf{T}$-cell activation by autologous human $\mathbf{T}$-cell leukemia virus type I-infected T-cell clones. Proceedings of the National Academy of Sciences USA 1989, 89:2 II0-2 II4.

7. Abraham RT, Wiederrecht G]: Immunopharmacology of rapamycin. Annual Reviews in Immunology 1996, I 4:483-5I0.

8. Raught B, Gingras AC, Sonenberg N: The target of rapamycin (TOR) proteins. Proc Natl Acad Sci U S A 200 I, 98:7037-7044.

9. Wullschleger $S$, Loewith $R$, Hall MN: TOR signaling in growth and metabolism. Cell 2006, I 24:47I-484.

10. Pende M, Um SH, Mieulet V, Sticker M, Goss VL, Mestan J, Mueller M, Fumagalli S, Kozma SC, Thomas G: S6KI(-/-)/S6K2(-/-) mice exhibit perinatal lethality and rapamycin-sensitive 5 '-terminal oligopyrimidine mRNA translation and reveal a mitogenactivated protein kinase-dependent S6 kinase pathway. Molecular and Cellular Biology 2004, 24:3 I I2-3124.

II. Ruvinsky I, Sharon N, Lerer T, Cohen H, Stolovich-Rain M, Nir T, Dor Y, Zisman P, Meyuhas O: Ribosomal protein S6 phosphorylation is a determinant of cell size and glucose homeostasis I 0. I I 0 I/gad.35 I 605. Genes Dev 2005, I 9:2 I 99-22 I I.

12. Holz MK, Ballif BA, Gygi SP, Blenis J: mTOR and S6KI mediate assembly of the translation preinitiation complex through dynamic protein interchange and ordered phosphorylation events. Cell 2005, I 23:569-580.

13. Jeffries HBJ, Fumagalli S, Dennis PB, Reinhard C, Pearson RB, Thomas G: Rapamycin suppresses 5' TOP mRNA translation through inhibition of p70s6k. The EMBO Journal 1997, 16:3693-3704.

14. Levy S, Avni D, Hariharan N, Perry RP, Meyuhas O: Oligopyrimidine tract at the 5 ' end of mammalian ribosomal protein mRNAs is required for their translational control. Proceeding of the National Academy of Sciences USA 1991, 88:3319-3323.

15. Terada N, Patel HR, Takase K, Kohno K, Nairn AC: Rapamycin selectively inhibits translation of mRNAs encoding elongation factors and ribosomal proteins. Proceedings of the National Academy of Sciences USA 1994, 91: I |477- I |481.

16. Rose NJ, Lever AML: The rapamycin sensitivity of human T-cell leukaemia virus type I-induced $\mathrm{T}$-cell proliferation is mediated independently of the polypyrimidine motifs in the 5 ' long terminal repeat. J Gen Virol 2001, 82:435-439.

17. Flint J, Shenk T: Viral transactivating proteins. Annual Reviews in Genetics 1997, 3 I:177-212.

18. Bosselut R, Duvall JF, Gégonne A, Bailly M, Hémar A, Brady J, Ghysdael J: The product of the c-ets-I proto-oncogene and the related Ets 2 protein act as transcriptional activators of the long terminal repeat of human T cell leukemia virus HTLVI. The EMBO Journal 1990, 9:3137-3|44. 
19. Bosselut R, Lim F, Rommond PC, Frampton J, Brady J, Ghysdael J: Myb protein binds to multiple sites in the human T-cell lymphotropic virus type I long terminal repeat and transactivates LTR-mediated expression. Virology 1992, 186:764-769.

20. Dasgupta P, Reddy CD, Saikumar P, Reddy EP: The cellular protooncogene product Myb acts as transcriptional activator of the long terminal repeat of human T-lymphotropic virus type I. Journal of Virology 1992, 66:270-276.

21. Dittmer J, Nordheim A: Ets transcription factors and human disease. Biochimica et Biophysica Acta 1998, 1377:FI-FI 2.

22. Weston $\mathrm{K}:$ Myb proteins in life, death and differentiation. Curr Opin Genet Dev 1998, 8:76-8I.

23. Oh IH, Reddy EP: The myb gene family in cell growth, differentiation and apoptosis. Oncogene 1999, 18:3017-3033.

24. Colgin MA, Nyborg JK: The human T-cell leukemia virus type I oncoprotein tax inhibits the transcriptional activity of c-Myb through competition for the CREB binding protein. J Virol 1998, 72:9396-9399.

25. Nicot C, Mahieux R, Opavsky R, Cereseto A, Wolff L, Brady JN, Franchini G: HTLV-I Tax transrepresses the human c-Myb promoter independently of its interaction with CBP or p300. Oncogene 2000, 19:2155-2164.

26. Nicot C, Mahieux R, Pise-Masison C, Brady J, Gessain A, Yamaoka S, Franchini G: Human T-Cell Lymphotropic Virus Type I Tax Represses c-Myb-Dependent Transcription through Activation of the NF-KB Pathway and Modulation of Coactivator Usage. Mol Cell Biol 200I, 21:739I-7402.

27. Beimling $P$, Moelling K: Direct interaction of CREB protein with 2 I bp Tax-response elements of HTLV-I LTR. Oncogene 1992, 7:257-262.

28. Jeang KT: Functional activities of the human T-cell leukemia virus type I Tax oncoprotein: cellular signaling through NFkappa B. Cytokine Growth Factor Rev 200I, I 2:207-2 17.

29. Toth CR, Hostutler RF, Baldwin ASJ, Bender TP: Members of the Nuclear Factor kappa B Family Transactivate the Murine cmyb Gene. J Biol Chem 1995, 270:766I-767I.

30. Alexandre $C$, Verrier B: Four regulatory elements in the human c-fos promoter mediate transactivation by the HTLV-I Tax protein. Oncogene |99|, 6:543-55|.

31. Grolleau A, Bowman J, Pradet-Balade B, Puravs E, Hanash S, GarciaSanz JA, Beretta L: Global and specific translational control by rapamycin in $\mathbf{T}$ cells uncovered by microarrays and proteomics. J Biol Chem 2002, 277:22175-22I84.

32. Phan SC, Feeley B, Withers D, Boxer LM: Identification of an inducible regulator of c-myb expression during $\mathrm{T}$-cell activation. Mol Cell Biol 1996, I6:2387-2393.

33. Roy J, Paquette JS, Fortin JF, Tremblay MJ: The immunosuppressant rapamycin represses human immunodeficiency virus type I replication. Antimicrob Agents Chemother 2002, 46:3447-3455.

34. Gewirtz A, Anfossi G, Venturelli D, Valpreda S, Sims R, Calabretta B: GI/S transition in normal human T-lymphocytes requires the nuclear protein encoded by c-myb. Science 1989, 245: $180-183$.

35. Rohwer F, Todd S, McGuire KL: The effect of IL-2 treatment on transcriptional attenuation in proto-oncogenes pim- $I$ and cmyb in human thymic blast cells. J Immunol 1996, 157:643-649.

36. Rose NJ, Richardson J, Desselberger U, Lever AML: Viral inactivation in a proportion of HTLV-I-infected T-cell clones arises through naturally occurring mutations. Journal of General Virology 2000, $81: 97-104$.

37. Sambrook J, Fritsch EF, Maniatis T: Molecular Cloning: A Laboratory Manual. 2nd edition. , Cold Spring Harbor Laboratory Press: 1989.

\section{Publish with Bio Med Central and every scientist can read your work free of charge}

"BioMed Central will be the most significant development for disseminating the results of biomedical research in our lifetime. "

Sir Paul Nurse, Cancer Research UK

Your research papers will be:

- available free of charge to the entire biomedical community

- peer reviewed and published immediately upon acceptance

- cited in PubMed and archived on PubMed Central

- yours - you keep the copyright

Submit your manuscript here:

http://www.biomedcentral.com/info/publishing_adv.asp
BioMedcentral 